\title{
The impact of promoting intergenerational synergy on the work engagement of older employees in Slovenia*
}

\author{
Maja Rožman, Sonja Treven, Vesna Čančer**
}

\begin{abstract}
Generational differences present a new aspect of diversity among employees in the workplace. The increasing number of older employees and negative attitudes of younger employees toward them create the need for better understanding between generations and the need to improve mutual cooperation among age-diverse employees in an organisation. The main objective of the paper is to determine the impact of intergenerational synergy on the work engagement of older employees in Slovenia. For this purpose, empirical research was conducted in medium-sized and large companies among employers and older employees in Slovenia. Factor analysis was used to replace a large number of statements with a smaller number of factors - new variables with which we performed a simple linear regression. Based on the results, we confirmed the hypothesis that promoting intergenerational synergy in companies has a statistically significant positive impact on the work engagement of older employees in Slovenia. In this context, companies should take the following measures: eliminate discrimination of older employees, promote intergenerational synergy, and promote intergenerational understanding between young and older employees.
\end{abstract}

Keywords: Intergenerational synergy, older employees, work engagement

JEL Codes: J24, I19, C38

\section{Introduction}

Demographic changes and age diversity in the workplace inspire new research. Today, diversity in the workforce is considered an important basis for successful companies which are customer-oriented and outward oriented. Therefore, the age diversity in companies needs to be recognised and valued, while at the same time, we must be aware that an appropriate environment should be created to respect the diversity of the workforce. The age diversity of employees must become a part of the general strategy of a company for equity and diversity (see e.g., Zaniboni/Truxillo/Fraccaroli/McCune/Bertolino 2014; Sanyal/Wilson/ Sweeney/Rachele/Kaur/Yates 2015).

* Received: 15.06.18, accepted: 31.05.19, 2 revisions.

** Rožman Maja, PhD, Assistant Professor, University of Maribor, Faculty of Economics and Business, Email: maja.rozman1@um.si, research interests: quantitative methods, structural equation modeling, age management

Treven Sonja, $\mathrm{PhD}$, Full professor of human resource management, University of Maribor, Faculty of Economics and Business, sonja.treven@um.si, research interests: human resources management, organisational behaviour, stress management, age management, management of employee diversity, international human resources management Cančer Vesna, $\mathrm{PhD}$, Full professor of quantitative methods in business science, University of Maribor, Faculty of Economics and Business, vesna.cancer@um.si, research interests: decision analysis, multiple criteria decision making, research methodology, creative problem solving, Industry 4.0. 
The percentage of older people will increase globally in the years to come; therefore, modern approaches are necessary to manage issues related to age in the workplace. In this respect, promotion of employees' quality of life, well-being, and solidarity between generations is needed (Ilmarinen 2012). Intergenerational cooperation is based on intergenerational learning, which provides transfer, exchange of knowledge and experience, and supportive assistance between generations. Unfortunately, according to Harvey (2012), employers do not pay attention to the management of older employees and are unaware of the importance of the intergenerational transfer of knowledge and experience of their employees. Older employees are often seen as an obstacle rather than an opportunity in terms of transferring knowledge and experience that should be built and exploited (Oliveira/Cardoso 2018). The effect of age discrimination of older people is reflected in practice in the dismissal of older employees, managers lacking the effort to retain them in the company, difficulties in accessing training and education, and particularly the working conditions that are not adapted to the needs of older people (Zaniboni et al. 2014).

Older employees face negative prejudices of employers regarding their age, ability, and efficiency. Age discrimination is a major problem in the labour market and in general among the elderly, since it affects the morale and productivity of older employees (Oliveira/Cabral-Cardoso 2018). Thus, intergenerational synergy contributes to the enhancement of intergenerational coexistence in the workplace, reduces the obstacles of discrimination and solves the problem of the presence of negative stereotypes between generations, which also leads to an increase in the work engagement of employees (Oliveira/Cabral-Cardoso 2017). Intergenerational synergy provides an effective way to maintain the competitive advantage of organisations (Ropes 2014).

Wagner and Harter (2006) state that there is a positive correlation between engagement, performance, and business results. The result is also reflected in greater customer satisfaction and loyalty, lower fluctuation and less absenteeism and presenteeisem, fewer accidents at work, higher profits, higher efficiency and productivity, and better quality of work. Harter and Adkins (2015) explain that engaged employees are less likely to have health problems. Research shows that unengaged employees face much more health problems than committed employees. Engaged and unengaged employees also differ in mood and exposure to stress. Engaged employees experience more moments of happiness and interest in work and have fewer moments when they experience stress and sadness. Therefore, the work and position of an individual influence his mood, which is then associated with health problems or stress.

The key task of managers is to enable all age-diverse employees to become and remain successful in their work. Maximum performance assurance is an in-depth and systematic way of managing the performance of all age-diverse employees 
in work organisations. This management method is based on the awareness that it is possible to achieve excellent performance if the manager creates a working environment where all age-diversified employees can improve their potential and are mutually interconnected. Thus, intergenerational synergy leads to an increase in the satisfaction, motivation, and work engagement of employees (see e.g., Profili/Innocenti/Sammarra 2017; Beazley/Ball/Vernon 2017).

The main objective of this research is to examine the promoting intergenerational synergy in the work engagement of older employees in Slovenia. This paper aims to verify the following hypothesis: Promoting intergenerational synergy in companies has a statistically significant positive impact on the work engagement of older employees in Slovenia.

This article provides a review of the literature, a description of the methodology, results about intergenerational synergy and its impact on work engagement of older employees, and finally a discussion of the findings.

\section{Literature review}

\subsection{Older employees}

Tikkanen and Nyhan (2006) summarise that statisticians tend to take the age of 45 as the demarcation between being a younger (24-44 years) or an older employee (45-64 years). Authors also summarise that other authors define older employees as those between 55 and 64 years of age.

Older employees are of key importance in maintaining the knowledge within a company; they are the holders of the so-called specific human capital, i.e. skills and capabilities that are specific to the organisation and are very difficult to transfer. The entire field of management evolves continuously. Human resource management must respond to the new challenges of an organisation's internal and external environment. In the context of demographic change, the management of older employees helps to shape new insights into the entire field of management and is an important element of the new managerial paradigm. According to the theory of competitive advantages of resources, older employees can be a very good resource of competitive advantages of an organisation (see e.g. Ilmarinen 2006; Davies/Hanley/Jenkins/Chan 2017).

Because of ageing, workforce employers should know how to manage the challenges of an ageing workforce (Truxillo/Fraccaroli 2013). The results of many studies show that older employees present an educated, reliable, experienced, and stable workforce (see, e.g. Vasconcelos 2015 b; Brooke 2003; Naegele/ Waleker 2006), therefore companies should reduce negative age stereotypes (Appelbaum/Wenger/Pachon Buitrago/Kaur 2016; Noack 2009). It is clear that there are stereotypes about older employees and their perceived lower trainability, lack of flexibility and poor cost-effectiveness when compared to younger 
workers. Yet, results from studies on age and skill obsolescence are inconsistent, suggesting either a positive, neutral or negative relationship between age and performance (Tikkanen/Nyhan 2006).

Organisations must find a new and proper way to retain older employees and exploit their skills and experience to the maximum extent, while at the same time allowing older employees to remain active in their field as long as possible (Jorgensen 2005).

\subsection{Discrimination of older employees and the need to establish intergenerational cooperation in the company}

Age discrimination refers to the discrimination of people due to their age and is defined as attributing certain characteristics, that are specific for a particular age group, without considering the actual personal characteristics of an individual (see, e.g. Roscigno/Mong/Byron/Tester 2007; Vasconcelos 2015 b).

Age discrimination has a significant negative impact on the working environment of older employees. Zaniboni et al. (2014) state that, at the older employees' workplaces, discrimination is most often reflected in selective employment policies, unequal training and education opportunities, unequal opportunities for promotion, inadequate work tasks, improper job creation (employees can be exposed to adverse effects), and underestimation of knowledge and experience of older employees.

Kooij/de Lange/Jansen/Dikkers (2008) also assert that the presence of discrimination and stereotypes has an impact on the employer's decisions and that older employees have limited opportunities for promotion, training, and development. However, this reduces not only the knowledge and development of older employees but also their success, satisfaction, and motivation for work.

Vasconcelos $(2015$ b) states that age discrimination occurs both in older and in younger people; therefore, the question arises whether some age groups are more affected by age discrimination. Therefore, the attitude towards older employees is more negative than towards younger employees, and older people are much more deprived of better working conditions than younger employees.

New approaches to addressing the age diversity of employees represent the first step towards the creation of the future human resources management policy that will focus on older employees and will thus consider demographic changes. Unfortunately, employers do not pay attention to the management of older employees and are unaware of the importance of intergenerational transfer of knowledge and experience of their employees (Harvey 2012). Posthuma and Campion (2009) explain that discrimination of older employees has long been a major problem within the workplace. Companies should consider many positive elements regarding the employment of older employees, but, unfortunately, many 
are not aware of them. Furthermore, many changes should be done to create a better working environment of older people that have not been implemented yet.

Some companies are aware of the problems stemming from the aging of the population and have a positive attitude towards age, but they do not appear to be bringing this issue to the forefront. Although some companies are changing their attitude towards older employees and this attitude is positive, they are still more inclined towards younger employees, which is reflected in the differences in rewards and recruitment (Kluge/Krings 2008; Rupčić 2018) as well as in training opportunities and poor cooperation between younger and older employees (Vasconcelos 2015b).

Despite the problems related to age and the aging of the population, a few organisations are aware of the need to develop and actualise intergenerational synergy in the company. In most cases, they approach the individual treatment of each case only when problems arise (see, e.g. Willet 2005; Vasconcelos 2015 a). Often, older employees are confronted with the dilemma of whether to stay or leave the organisation, while the managers do not look for creative ways to retain them in the organisation (see, e.g. Zaniboni et al. 2014; Vasconcelos $2015 a)$.

\subsection{Promoting intergenerational synergy and engagement of older employees at the workplace}

Due to demographic changes, managers should pay more attention to generational differences and to the creation of intergenerational synergies (Hertel/van der Heijden/de Lange/Deller 2013; Beazley et al. 2017). Intergenerational cooperation in the workplace requires a thorough change of the relationship between employees and the organisation management. Management must abandon the wrong assumptions and prejudices about the diversity of employees (Beazley et al. 2017).

Today, organisations are constantly facing social development, such as globalisation, technological improvements, and increasing global competition (Rupčić 2018; Beazley et al. 2017). In addition to economic evolution and demographic change, which create pressure and new challenges for human resources management, organizations must compete with other companies. Therefore, it becomes increasingly important for organisations to retain talented and skilled employees, since this is crucial for achieving business growth and maintaining competitive advantage (Walker 2012; Rupčić 2018).

According to Harvey (2012), Beazley et al. (2017), and Profili et al. (2017), intergenerational cooperation positively influences the results of age-diversified employees, especially when they have to solve difficult and complex tasks, since the diversity of employees' knowledge, competences, and experience can be ex- 
pressed. Organisations must focus on intergenerational synergy, maximise the positive effect of all generations, and combine their benefits; thus, they can gain the most and the best from each generation separately and all together. Intergenerational cooperation is successfully implemented through age-diverse teams and mentoring schemes among employees, which is reflected in the transfer of a large quantity of knowledge, experience, and continuous organisational learning.

Profili et al. (2017) and Rupčić (2018) summarise that intergenerational cooperation, and thus the exchange of knowledge, is positively related to the reduction of production costs, faster completion of new development products, variety of projects, increased team performance and innovation, and increased sales growth and revenue.

The impact of employee aging on work engagement depends heavily on the individual workplace and the specific work that the employee performs in the organisation. Companies will have to pay more attention to the creation of an appropriate working environment, which contributes to the positive performance of age-diverse employees in all fields (Lopes Costa/ Passos/Bakker 2016). Kooij/de Lange/Jansen/Dikkers (2008) explain the importance of the impact of human resource management on the work engagement of older employees, since the proper management of older employees with training opportunities and rewards for good work, provision of flexibility at the workplace, and ensuring a favourable working environment and good interpersonal relationships increase the work commitment of employees. According to Macey/Schneider (2008) and Bakker/Albrecht/Leiter (2011), the work engagement of employees is the key to the successful function of the entire organisation, since engaged employees feel an energetic and comfortable connection with their work. Furthermore, they consider themselves efficient and capable of successfully performing their work, feel better, and are healthier.

Promoting intergenerational synergy and attaining the engagement of older employees at the workplace is very important for the successful operation of companies. Managers should be aware of the importance of work engagement among their employees and must find ways to help age-diverse employees to contribute to engagement in the workplace through different age periods (Zaniboni et al. 2014; Sanyal et al. 2015). Ariani (2013) explains that the work engagement of employees changes over different periods. Based on this point of view, organisations must be aware of the role of human resource management, since they can only thus establish how employees think and feel about their work responsibilities. 


\subsection{Promoting intergenerational synergy-a part of the organisation's strategy}

Strategic human resource management should support the intensive intergenerational exchange of knowledge and experience among employees of different ages, since this enables life-long learning in the organisation (Argote/McEvily/ Reagans 2003). Hertel et al. (2013) argue that the diversity of employees and mutual cooperation can increase creativity, innovation, and problem solving due to the broader perspective and different knowledge of employees.

Age diversity of employees has a beneficial impact on the team's work results, through which members must solve difficult and complex tasks, since the diversity of team members' knowledge, competences, and experience can be expressed (Cheung/Wu 2013; Rupčić 2018). Cheung and Wu (2013) and Argote et al. (2003) emphasise that human resource management should support intensive intergenerational exchange of knowledge among employees of different ages, since this enables life-long learning in the organisation. Therefore, promoting intergenerational synergy has to be a part of the organization's strategy.

Creating awareness of the diversity of generations and accepting and appreciating them present the first stage of optimising age diversity. Age discrimination is detrimental to the success of all organisations, since it causes unnecessary waste of talents, skills, knowledge, and experience of age-diverse employees. A diverse organisation breaks down stereotypes related to older employees, does not use age as a criterion for making any personnel decisions, creates a pleasant working environment, cares for employees' engagement, builds competitive advantages on the basis of intergenerational coexistence and motivated employees of all ages, and builds the reputation as an ethical employer (Jorgensen 2005; The Employers Forum on Age 2015).

Also, intergenerational cooperation activities are classified into three groups (Age Concern England 2014): (1) Solidarity between generations (one generation provides the support to other); (2) Intergenerational cooperation in the strict sense (different generations working together on a specific project with specific objectives); and (3) Intergenerational learning (one generation learns from the other and vice versa; different generations at the same time learn together). Methods of how an organization can implement intergenerational cooperation in the workplace include mentoring schemes, job rotation, job sharing, intergenerational management, talent management and coaching (Foundation for the Improvement Of Employment Opportunities 2012).

\subsection{Work engagement and its benefits for the company}

Work engagement is defined as a positive, fulfilling, work-related state of mind that is characterized by vigor, dedication, and absorption (see, e.g. Karanika- 
Murray/Duncan/Halley/Griffiths 2015; Bakker/ Demerouti 2008). Vigor is characterized by high levels of energy and mental resilience while working (Schaufeli/Bakker 2004). According to Schaufeli and Bakker (2004), dedication refers to being strongly involved in one's work and experiencing a sense of significance, enthusiasm, and challenge. Absorption is characterized by being fully concentrated and happily engrossed in one's work, whereby time passes quickly and one has difficulties with detaching oneself from work (see e.g., Bakker/ Demerouti 2008). In short, engaged employees have high levels of energy and are enthusiastic about their work. Moreover, they are often fully immersed in their work so that time flies (see e.g., May/Gilson/Harter 2004).

Bakker (2009) emphasizes that there are four reasons that make engaged workers perform better than non-engaged workers: engaged workers experience positive emotions such as happiness, enthusiasm, and joys; they have better health; they are able to create their own job and personal resources and they often transfer their engagement to others.

Recent research has shown that engaged employees often experience positive emotions (Schaufeli/Salanova 2007), and this may be the reason why they are more productive. Happy people are more sensitive to opportunities at work, more outgoing and helpful to others, and more confident and optimistic (Cropanzano/Wright 2001). Research suggests that engagement is positively related to health, and this would imply that engaged workers are better able to perform well. Demerouti/Bakker/De Jonge/Janssen/Schaufeli (2001) found moderate negative correlations between engagement and psychosomatic health complaints (e.g., headaches, chest pain).

There are also some differences between work engagement, satisfaction and motivation. An employee can be satisfied with a job without being engaged in the job. Employee engagement is much more than being content with, for example, pay. That contentedness is merely job satisfaction, and though satisfaction is generally enough to retain employees, it is not enough to ensure productivity. On the other hand, employee engagement does promote increased productivity (see, e.g. $\mathrm{Lu} \mathrm{L} / \mathrm{Lu} \mathrm{A} /$ Gursoy/Neale, 2016; Bakker 2009). An engaged employee is an employee who is deeply involved and invested in their work. Employee satisfaction is the foundation upon which employee engagement can grow and thrive (Vincent-Höper/Muser/Janneck 2012). Employees are motivated by the prospect of getting a bonus, benefit or recognition. They may even be motivated to take on more responsibilities and get promoted. In this case, employees are motivated but they are not engaged (Jr/Finkel/Fitzsimons/Gino 2017; Vincent-Höper et al. 2012). Employee motivation is the level of energy and enthusiasm an employee brings to his/her workplace. The motivation factors can be intrinsic or extrinsic and vary from one person to the other. Work engagement is an approach, that results in giving an appropriate condition to all the employee in a workplace. It 
is more of a fundamental concept to understand the qualitative and quantitative relationship between the employees and their workplace ( $\mathrm{Jr}$ et al. 2017; Putra/Cho/Liu 2015).

Organizations may increase employee engagement by using particular HRMstrategies. For instance, employee engagement can be improved through better job design by using the motivating potential of job resources. Also job rotation and changing jobs might result in higher engagement levels because it challenges employees, increases their motivation, and stimulates learning and professional development (Schaufeli 2012). According to Garg/Dar/Mishra (2018), job satisfaction enhances work engagement and is also the key driver of work engagement. Alzyoud (2018) on the basis of his research explains that employees who are satisfied with their job are more engaged in the workplace. Furthermore, the results demonstrate that employees who worked in a low trust environment tend to be less engaged with their work as compared to those who worked in ahigh trust environment. This finding can be attributed to the explanation that individuals who are happy and satisfied at work are generally more motivated and engaged in the workplace, despite the challenges they face. It is thus expected that highly satisfied people at work are also highly engaged in their work.

Employee engagement is critical to the success of an organization and employee performance. Engagement is a result of employees understanding the company's goals and their role in helping the organization reach those goals. If they believe their goals align with the business strategy, they will have a bigger stake in the outcome and become higher performers. Measurement is the first and most critical step in improving employee engagement. Thus, there are various questionnaires on the basis of which companies can measure the engagement of their employees (see, e.g. Li 2018; Pham-Thai/McMurray/Muenjohn/Muchiri 2018; Guan/Frenkel 2018; Macey/Schneider 2008; Robertson/Cooper 2010).

\subsection{Impact of intergenerational synergy on the engagement of older employees}

An important task of the management is to increase concern for the work engagement of age-diverse employees. Employers must consider the factors that can influence the work engagement of employees. By promoting intergenerational synergy in the workplace, the work results of employees are improved, the level of their work performance is increased, the exchange of knowledge and experience is implemented, and work engagement of employees is strengthened. This contributes to the development, growth, performance, innovation, and competitiveness of a company (see, e.g. Albrecht/Breidahl/Mart 2018; Sanyal et al. 2015; Ariani 2013). An appropriate working environment is essential for the work engagement of older employees. Managers have the greatest impact on the 
level of employees' work engagement. Yiing and Ahmad (2009) add that a change of the relationship with older employees within organisations and a greater emphasis on intergenerational synergy are needed, since, in the case of employees who are dissatisfied with the workplace and management, this leads to less work engagement or lack of work engagement, less commitment to the organisation, lower motivation, and poor performance.

Albrecht et al. (2018) consider that only those organisations that emphasise and focus on the work engagement of their employees increase the work performance of their employees; this consequently influences the growth and development of the company. According to Xu and Thomas (2011) and Grum and Saks (2011), the work engagement of employees influences the company's business results, productivity, fluctuation, absenteeism and presenteeism of employees, and customer satisfaction and loyalty. However, this can only be achieved with an appropriate design of the work environment and the promotion of intergenerational synergy.

It is important to create such a working environment in which older employees feel good at work. Engagement of employees is reinforced when employees feel good at work, and vice versa - the work engagement of employees is reduced when the level of well-being is low among employees (Robertson/Cooper 2010; Ariani 2013). Negative stereotypes, prejudices, and discrimination should not be overlooked in creating a favourable work environment for older employees and thereby enhance work engagement. The stereotypes of older employees, and thus discrimination against the elderly, pose a serious problem. Stereotypical beliefs about aging and older employees can affect employers' decisions, which is reflected in limited opportunities for promotion and training and in limitation of different work opportunities for older employees in a company. This also reduces the engagement of older employees at the workplace (Kooij et al. 2008).

The employment rate of older employees is much lower, particularly in the 5964 age group in 2015 it was 15.9 percent, compared to 38.2 percent in EU28 and 47.5 percent in OECD countries (Ministry of labour, family, social affairs and equal opportunities 2017)

Yet, it is not just the older age of the employees we refer to as a changing factor. Due to demographic changes companies will increasingly feel the lack of younger workforce. The challenges for employers are in the new ways of merging potentials of all generations. Differences between generations are big because of different values, because of the ways of working and cooperating and because of people's expectations (Prizma 2018). Žnidaršič and Dimovski (2010) emphasise that it is crucial that enterprises find common points of cooperation among employees, similarities among generations on which they can build mutual relations. Žnidaršič (2010) recognises the solution in combining wisdom and innovativeness of employees, in the development of new forms of solidarity, 
mutual support, learning and transfer of knowledge and experience among generations in enterprises. Also, all of these activities can lead to work engagement of employees.

Based on the literature review we formulated a research model that is shown in Figure 1. We followed the research process described by Kumar $(2005,21)$.

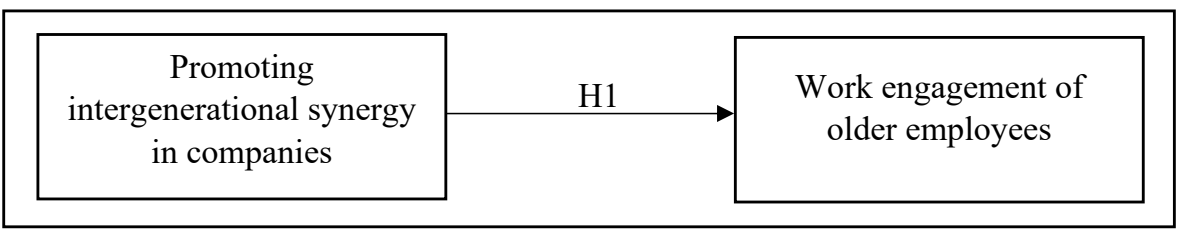

Figure 1: Research model

Based on the literature review we formulated a hypothesis H1: Promoting intergenerational synergy in companies has a statistically significant positive impact on the work engagement of older employees in Slovenia.

\section{Methodology}

\subsection{Data and Sample}

We carried out an empirical study on intergenerational synergy and its impact on the work engagement of older employees in 1,000 randomly selected large- and medium-sized companies in Slovenia from July 2016 to February 2017. The main survey involved 472 employers (the response rate was $47.2 \%$ ) and 1086 older employees who responded to the questionnaire. In each large- and medium-sized company we selected up to 4 employees to participate in our research. Respondents answered at least $85 \%$ of the questions, and we did not exclude any questionnaires.

The structure of employers that participated in the survey was as follows:

- Regarding the achieved education level of employers who participated in the research, $62.9 \%$ of the respondents finished high professional or university education, $21.6 \%$ of the respondents have a master's degree or doctorate, $14.4 \%$ of the respondents finished college, and the smallest percentage presents respondents who finished vocational training or high school (1.1\%).

- According to the length of service of the respondents, $71.2 \%$ of employers with the length of service from 31 to 40 years were included in the research. In second place were respondents with a length of service from 21 to 30 years $(25.0 \%)$. A low percentage of respondents had a length of service of more than 41 years $(2.3 \%)$ and respondents with a length of service from 11 to 20 years $(1.5 \%)$. 
- The biggest share in the research represented large companies (51.9\%). Medium-sized companies comprised $48.1 \%$.

- The majority of the respondents included in the research perform their work in the Central Slovenia region (38.3\%), Drava region (18.2\%), and Mura region $(10.4 \%)$. The smallest percentages are in the Central Sava region $(0.2 \%)$, Lower Sava region, $(1.1 \%)$ and Littoral-Inner Carniola region $(1.3 \%)$.

- The most respondents $(30.7 \%)$ perform their work in processing activities. This is followed by trade, maintenance, and repair of motor vehicles (16.9\%); professional, scientific, and technical activities (10.2\%); financial and insurance activities (10.0\%); information and communication activities (7.8\%); construction sector (4.7\%); other diverse business activities (3.4\%); real estate services $(3.2 \%)$; health and social security (3.2\%); catering $(2.5 \%)$; supply of electricity, gas, and steam (2.3\%); traffic and storage (2.1\%); agriculture and hunting, forestry, and fishing (1.3\%); water supply, sewage and waste management, and remediation activities $(0.8 \%)$; mining $(0.4 \%)$; and other activities $(0.4 \%)$.

The structure of older employees that participated in the survey was as follows:

- The completed questionnaire comprised $41.8 \%$ of older employees aged from 56 to 61 years, $38.4 \%$ employees aged from 50 to 55 years, and $19.3 \%$ employees aged from 62 to 67 years. The lowest percentage is presented by older employees aged over $68(0.6 \%)$ years.

- The biggest share of companies in which older employees are employed present large companies (54.3\%). Medium-sized companies comprised $45.7 \%$.

- The companies in which older employees are employed were from manufacturing $(30.3 \%)$; trade, maintenance, and repair of motor vehicles $(16.4 \%)$; financial and insurance activities (11.0\%); professional, scientific, and technical activities (10.9\%); information and communication activities $(7.6 \%)$; construction (4.4\%); other diversified business activities (3.4\%); real estate business (3.4\%); catering (2.8\%); health and social care (2.4\%); supply of electricity, gas, and steam (2.2\%); transport and storage (1.8\%); agriculture and hunting, forestry, and fishing (1.2\%); water supply, sewage and waste management, and environmental rehabilitation (1,0\%); other activities $(0.7 \%)$; and mining $(0.4 \%)$.

\subsection{Research instrument}

When designing the instrument for measuring the intergenerational synergy and its impact on work engagement of older employees, we relied on the various theoretical principles and research of several authors. Statements for the intergenerational synergy were formed by Naegele and Walker (2006) and Agrawal 
(2012). Statements for the engagement of older employees were formed by Macey and Schneider (2008) and Robertson and Cooper (2010). To determine the intergenerational synergy in companies in Slovenia, the employers indicated on a 5-point Likert-type scale their agreement to the listed statements, indicated as follows: $1-\mathrm{I}$ completely disagree, $2-\mathrm{I}$ do not agree, $3-\mathrm{I}$ partially agree, $4-\mathrm{I}$ agree, 5-I completely agree.

At the beginning of the questionnaire used in preliminary and main research, we explained to respondents what intergenerational synergy is. Intergenerational synergy is based on intergenerational learning, which provides transfer and exchange of knowledge and experience in the field of work, and solidarity between generations (see, e.g. Rupčić 2018; Henkin/Butts 2012). In preliminary research, respondents had the opportunity to give comments if the questions were not clear.

Table 1 shows the statements of several authors that we included in our questionnaire.

Table 1: Statements of several authors in the questionnaire

\begin{tabular}{|c|c|c|}
\hline Dimension & Statements & Source \\
\hline \multirow{6}{*}{$\begin{array}{l}\text { Intergenera- } \\
\text { tional } \\
\text { synergy }\end{array}$} & $\begin{array}{l}\text { In the company we emphasise intergenerational syn- } \\
\text { ergy. }\end{array}$ & $\begin{array}{l}\text { Naegele and Walker } \\
\text { (2006); Agrawal (2012) }\end{array}$ \\
\hline & $\begin{array}{l}\text { Through intergenerational cooperation, we increase } \\
\text { the innovation and creativity of our employees at } \\
\text { work. }\end{array}$ & $\begin{array}{l}\text { Naegele and Walker } \\
(2006)\end{array}$ \\
\hline & $\begin{array}{l}\text { Through intergenerational cooperation we enable em- } \\
\text { ployees to create quicker solutions and make faster } \\
\text { decisions. }\end{array}$ & $\begin{array}{l}\text { Naegele and Walker } \\
\text { (2006) }\end{array}$ \\
\hline & $\begin{array}{l}\text { Through intergenerational cooperation, we allow the } \\
\text { distribution of work tasks, and with this we thereby } \\
\text { reduce the workload of employees. }\end{array}$ & Agrawal (2012) \\
\hline & $\begin{array}{l}\text { Through intergenerational cooperation, we place em- } \\
\text { phasis on better understanding of different age pro- } \\
\text { files of customer and their needs. }\end{array}$ & $\begin{array}{l}\text { Naegele and Walker } \\
(2006)\end{array}$ \\
\hline & $\begin{array}{l}\text { Through intergenerational cooperation we exploit the } \\
\text { benefits of age diversity among our employees. }\end{array}$ & $\begin{array}{l}\text { Naegele and Walker } \\
\text { (2006); Agrawal (2012) }\end{array}$ \\
\hline
\end{tabular}




\begin{tabular}{|c|c|c|}
\hline Dimension & Statements & Source \\
\hline \multirow{12}{*}{$\begin{array}{l}\text { Work } \\
\text { engagement }\end{array}$} & I do my work with passion. & $\begin{array}{c}\text { Macey and Schneider } \\
\text { (2008); Robertson and } \\
\text { Cooper (2010) }\end{array}$ \\
\hline & I am engaged in the quality of my work. & $\begin{array}{l}\text { Macey and Schneider } \\
\text { (2008) }\end{array}$ \\
\hline & $\begin{array}{l}\text { I am engaged in the task of achieving successful busi- } \\
\text { ness results. }\end{array}$ & $\begin{array}{c}\text { Macey and Schneider } \\
\text { (2008); Robertson and } \\
\text { Cooper (2010). }\end{array}$ \\
\hline & I feel connection with the company in which I work. & $\begin{array}{l}\text { Macey and Schneider } \\
\text { (2008) }\end{array}$ \\
\hline & $\begin{array}{l}\text { I am aware of the importance of innovation for our } \\
\text { company, and I am helping to develop the company. }\end{array}$ & $\begin{array}{l}\text { Robertson and Cooper } \\
\text { (2010) }\end{array}$ \\
\hline & I trust my colleagues and the manager. & $\begin{array}{l}\text { Robertson and Cooper } \\
\text { (2010) }\end{array}$ \\
\hline & I feel that my work and job are important. & $\begin{array}{c}\text { Macey and Schneider } \\
\text { (2008); Robertson and } \\
\text { Cooper (2010) }\end{array}$ \\
\hline & I am proud to be employed with this company. & $\begin{array}{c}\text { Robertson and Cooper } \\
\text { (2010) }\end{array}$ \\
\hline & $\begin{array}{l}\text { I believe in the successful development and operation } \\
\text { of our company. }\end{array}$ & $\begin{array}{c}\text { Macey and Schneider } \\
\text { (2008); Robertson and } \\
\text { Cooper (2010) }\end{array}$ \\
\hline & $\begin{array}{l}\text { I would not leave the company, even if I had an oppor- } \\
\text { tunity for another job. }\end{array}$ & $\begin{array}{l}\text { Robertson and Cooper } \\
\text { (2010) }\end{array}$ \\
\hline & I feel very good in my workplace. & $\begin{array}{c}\text { Macey and Schneider } \\
\text { (2008); Robertson and } \\
\text { Cooper (2010). }\end{array}$ \\
\hline & I feel like "part of the family" in the company. & $\begin{array}{l}\text { Macey and Schneider } \\
(2008)\end{array}$ \\
\hline
\end{tabular}

\subsection{Statistical Analysis}

Within the empirical portion of study, we used descriptive statistics and factor analysis to describe the factor with certain variables. We wanted to establish whether the use of factor analysis is reasonable on the basis of Kaiser-MeyerOlkin's measure of sampling adequacy (KMO $\geq 0.5$ ) (Kaiser 1974) and Bartlett's test of sphericity. Based on the results of factor analysis, we did not eliminate any variable, because communalities were higher than 0.40 (Costello/ Osborne 2005).

We checked the reliability of the measurement of research within the scope of inner consistency with the Cronbach's alpha coefficient (Cronbach 1951:297334). Churchill and Brown (2004:337) define the indicators of highly reliable constructs as highly connected and show that all of them measure the same la- 
tent construct. The authors state that the reliability of the measurement that has a coefficient of $\alpha \geq 0.80$ is marked as exemplary, as very good if the coefficient is in the interval $0.70 \leq \alpha<0.80$, as moderate in the interval $0.60 \leq \alpha<0.70$, and as barely acceptable if the coefficient $\alpha$ is smaller than 0.60 .

We saved the derived factor points and thus created new variables (factors). Based on the gained new variables (factors), we performed a simple regression analysis. We checked the quality of the obtained regression model with the correlation coefficient, determination coefficient, F-test, and t-test.

\section{Results}

\subsection{Intergenerational synergy in Slovenian companies}

Table 2 presents the results of descriptive statistics for answers about the construct intergenerational synergy in companies in Slovenia.

Table 2: Descriptive statistics for answers about the construct intergenerational synergy in companies

\begin{tabular}{|l|c|c|c|c|}
\hline \multicolumn{1}{|c|}{ Statement } & N & Median & Mean & $\begin{array}{c}\text { Standard } \\
\text { Deviation }\end{array}$ \\
\hline $\begin{array}{l}\text { In the company we emphasise the intergenera- } \\
\text { tional synergy. }\end{array}$ & 471 & 4.00 & 3.71 & 0.931 \\
\hline $\begin{array}{l}\text { Through intergenerational cooperation, we in- } \\
\text { crease the innovation and creativity of our em- } \\
\text { ployees at work. }\end{array}$ & 472 & 4.00 & 3.76 & 0.919 \\
\hline $\begin{array}{l}\text { Through intergenerational cooperation we en- } \\
\text { able that employees make quicker solutions and } \\
\text { decisions. }\end{array}$ & 472 & 4.00 & 3.74 & 0.950 \\
\hline $\begin{array}{l}\text { Through intergenerational cooperation, we al- } \\
\text { low the distribution of work tasks and with this } \\
\text { we thereby reduce the workload of employees. }\end{array}$ & 472 & 4.00 & 3.73 & 0.933 \\
\hline $\begin{array}{l}\text { Through intergenerational cooperation, we give } \\
\text { emphasis on better understanding of different } \\
\text { age profiles of customer and their needs. }\end{array}$ & 471 & 4.00 & 3.71 & 0.987 \\
\hline $\begin{array}{l}\text { Through intergenerational cooperation we ex- } \\
\text { ploit the benefits of age diversity of our employ- } \\
\text { ees. }\end{array}$ & 471 & 4.00 & 3.76 & 0.929 \\
\hline
\end{tabular}

Descriptive statistic for answers about the intergenerational synergy in companies in Table 2 shows that on average employers agree with all statements. The highest average agreement is achieved by the statements "Through intergenerational cooperation, we increase the innovation and creativity of our employees at work" (mean: 3.76) and "Through intergenerational cooperation we exploit the benefits of age diversity of our employees" (mean: 3.76). The highest dispersion of responses (standard deviation) is noted in the statement "Through 
intergenerational cooperation, we give emphasis on better understanding of different age profiles of customer and their needs."

Table 3 presents the results of factor analysis for the construct intergenerational synergy. In the questionnaire for employers, intergenerational synergy was measured with six items. The value of the Kaiser-Meyer-Olkin measure of sampling adequacy $(\mathrm{KMO}=0.933)$ and the results of Bartlett's test of sphericity (Approx. Chi-Square $=5207.639, \mathrm{df}=15, \mathrm{p}<0.001)$ suggested the use of factor analysis.

Table 3: The results of factor analysis for the construct promoting intergenerational synergy

\begin{tabular}{|l|c|c|}
\hline \multicolumn{1}{|c|}{ Items } & Communalities & $\begin{array}{c}\text { Factor } \\
\text { loadings }\end{array}$ \\
\hline In the company we emphasise intergenerational synergy. & 0.934 & 0.979 \\
\hline $\begin{array}{l}\text { Through intergenerational cooperation, we increase the in- } \\
\text { novation and creativity of our employees at work. }\end{array}$ & 0.951 & 0.975 \\
\hline $\begin{array}{l}\text { Through intergenerational cooperation we enable employ- } \\
\text { ees to create quicker solutions and make faster decisions. }\end{array}$ & 0.940 & 0.969 \\
\hline $\begin{array}{l}\text { Through intergenerational cooperation, we allow the dis- } \\
\text { tribution of work tasks, and with this we thereby reduce } \\
\text { the workload of employees. }\end{array}$ & 0.910 & 0.966 \\
\hline $\begin{array}{l}\text { Through intergenerational cooperation, we place emphasis } \\
\text { on better understanding of different age profiles of cus- } \\
\text { tomer and their needs. }\end{array}$ & 0.862 & 0.954 \\
\hline $\begin{array}{l}\text { Through intergenerational cooperation, we exploit the } \\
\text { benefits of age diversity among our employees. }\end{array}$ & 0.958 & 0.929 \\
\hline Kaiser-Meyer-Olkin measure: 0.933 & & \\
\hline Cumulative percentage of explained variance: $92.6 \%$ & \\
\hline
\end{tabular}

The values of all communalities in Table 3 for construct intergenerational synergy are higher than 0.80 , therefore we have not eliminated any variable. The total variance explained is $92.6 \%$. Table 1 also shows that all factor loadings are higher than 0.90 . In our case, the most important factor in intergenerational synergy is as follows: "In the company we emphasise intergenerational synergy."

The value of Cronbach's alpha for the factor intergenerational synergy is 0.984 , therefore, the reliability of the measurement in the intergenerational synergy is exemplary.

\subsection{Work engagement of older employees}

Table 4 presents the results of descriptive statistics for answers about work engagement for older employees. 
Table 4: Descriptive statistics for answers about work engagement for older employees

\begin{tabular}{|l|c|c|c|c|}
\hline \multicolumn{1}{|c|}{ Statement } & $\mathrm{N}$ & Median & Mean & $\begin{array}{c}\text { Standard } \\
\text { Deviation }\end{array}$ \\
\hline I do my work with passion. & 1084 & 4.00 & 3.60 & 1.019 \\
\hline I am engaged to the quality of my work. & 1084 & 4.00 & 4.16 & 0.802 \\
\hline $\begin{array}{l}\text { I am engaged to achieve successful business re- } \\
\text { sults. }\end{array}$ & 1084 & 4.00 & 4.07 & 0.902 \\
\hline $\begin{array}{l}\text { I feel connection with the company in which I } \\
\text { worked. }\end{array}$ & 1084 & 4.00 & 3.63 & 1.124 \\
\hline $\begin{array}{l}\text { I am aware of the importance of innovation for } \\
\text { our company and I am helping to develop the } \\
\text { company. }\end{array}$ & 1084 & 4.00 & 3.92 & 0.973 \\
\hline I trust in my colleagues and the manager. & 1084 & 4.00 & 4.04 & 0.880 \\
\hline I feel that my work and job are important. & 1084 & 4.00 & 3.69 & 1.128 \\
\hline I am proud to be employed in this company. & 1084 & 4.00 & 3.79 & 1.044 \\
\hline $\begin{array}{l}\text { I believe in the successful development and op- } \\
\text { eration of our company. }\end{array}$ & 1084 & 4.00 & 4.00 & 0.900 \\
\hline $\begin{array}{l}\text { I would not leave the company, even if I could } \\
\text { get another opportunity for job. }\end{array}$ & 1084 & 4.00 & 3.37 & 1.225 \\
\hline I feel very well at my workplace. & 1084 & 4.00 & 3.40 & 1.270 \\
\hline I feel like a "part of the family" in the company. & 1084 & 4.00 & 3.36 & 1.263 \\
\hline
\end{tabular}

Descriptive statistic for answers about the work engagement of older employees in Table 4 shows that, on average, older employees partially agree or agree that they are engaged in their workplace. On average, older employees partially agree with the statements: »I would not leave the company, even if I could get another opportunity for job«, »I feel very well at my workplace«, »I feel like a "part of the family" in the company «, and agree with other statements. The highest average agreement is achieved by the statements: "I am engaged to the quality of my work." The highest dispersion of responses (standard deviation) is noted in the statement "I feel very well at my workplace."

Table 5 presents the results of factor analysis for the construct work engagement of older employees. In the questionnaire for older employees, work engagement was measured with twelve items. The value of Kaiser-Meyer-Olkin measure of sampling adequacy $(\mathrm{KMO}=0.961)$ and the results of Bartlett's test of sphericity 
(Approx. Chi-Square $=21971.451, \mathrm{df}=66, \mathrm{p}<0.001$ ) suggest the use of factor analysis.

Table 5: The results of factor analysis for the construct work engagement of older employees

\begin{tabular}{|l|c|c|}
\hline \multicolumn{1}{|c|}{ Items } & Communalities & Factor loadings \\
\hline I do my work with passion. & 0.807 & 0.948 \\
\hline I am engaged in the quality of my work. & 0.815 & 0.936 \\
\hline $\begin{array}{l}\text { I am engaged in the task of achieving successful business } \\
\text { results }\end{array}$ & 0.807 & 0.934 \\
\hline I feel connection with the company in which I work. & 0.871 & 0.933 \\
\hline $\begin{array}{l}\text { I am aware of the importance of innovation for our com- } \\
\text { pany, and I am helping to develop the company. }\end{array}$ & 0.832 & 0.930 \\
\hline I trust my colleagues and the manager. & 0.835 & 0.929 \\
\hline I feel that my work and job are important. & 0.873 & 0.920 \\
\hline I am proud to be employed with this company. & 0.900 & 0.914 \\
\hline $\begin{array}{l}\text { I believe in the successful development and operation of } \\
\text { our company. }\end{array}$ & 0.863 & 0.912 \\
\hline $\begin{array}{l}\text { I would not leave the company, even if I had an opportu- } \\
\text { nity for another job. }\end{array}$ & 0.847 & 0.903 \\
\hline I feel very good in my workplace. & 0.865 & 0.899 \\
\hline I feel like "part of the family" in the company & 0.876 & 0.898 \\
\hline Kaiser-Meyer-Olkin measure: 0.961 & & \\
\hline Cumulative percentage of explained variance: 84.931\% & & \\
\hline
\end{tabular}

The values of all communalities in Table 5 for work engagement of older employees are higher than 0.80 , therefore we have not eliminated any variable. The total variance explained is $84.9 \%$. All factor loadings are higher than 0.80 . In our case, the most important factor in work engagement of older employees is "I do my work with passion."

The value of the Cronbach's alpha for the factor work engagement of older employees is 0.982 , therefore the reliability of the measurement in the work engagement of older employees is exemplary.

\subsection{The impact of promoting intergenerational synergy on work engagement of older employees in Slovenia}

After saving the factor scores as new variables, we performed a regression analysis to verify the following hypothesis: Promoting intergenerational synergy in companies has a statistically significant positive impact on the work engagement of older employees in Slovenia. In the continuation, we present the results of testing of the hypothesis. The value of correlation coefficient between the de- 
pendent variable (work engagement of older employees) and independent variable (promoting intergenerational synergy) for hypothesis $\mathrm{H} 1$ is $\mathrm{r}=0.760$, which indicates that there is a moderate connection between the variables. The value of the determination coefficient is 0.578 . The determination coefficient explains that $57.8 \%$ of the variance of the dependent variable (work engagement of older employees) is explained with the variance of the independent variable (promoting intergenerational synergy). We have established the reliability of the derived regression function with the F-test: $F=1478.484$. The regression function is reliable $(\mathrm{p}<0.001)$. Table 6 shows the regression analysis results.

Table 6: Regression analysis results

\begin{tabular}{|c|c|c|c|c|c|c|c|}
\hline \multirow[b]{2}{*}{$\begin{array}{l}\text { Hypo- } \\
\text { thesis }\end{array}$} & \multirow[b]{2}{*}{$\begin{array}{c}\text { Depen- } \\
\text { dent } \\
\text { variable }\end{array}$} & \multirow[b]{2}{*}{$\begin{array}{c}\text { Indepen- } \\
\text { dent } \\
\text { variable }\end{array}$} & \multicolumn{2}{|c|}{$\begin{array}{l}\text { Unstandardised } \\
\text { coefficients }\end{array}$} & \multirow{2}{*}{$\begin{array}{c}\begin{array}{c}\text { Standardised } \\
\text { coefficients }\end{array} \\
\text { Beta }\end{array}$} & \multirow[b]{2}{*}{$\mathbf{t}$} & \multirow[b]{2}{*}{$\begin{array}{r}\text { Signifi- } \\
\text { cance }\end{array}$} \\
\hline & & & B & $\begin{array}{c}\text { Standard } \\
\text { error }\end{array}$ & & & \\
\hline $\mathrm{H} 1$ & $\begin{array}{l}\text { Work en- } \\
\text { gage- } \\
\text { ment of } \\
\text { older } \\
\text { employ- } \\
\text { ees }\end{array}$ & $\begin{array}{l}\text { Promot- } \\
\text { ing inter- } \\
\text { genera- } \\
\text { tional } \\
\text { synergy }\end{array}$ & 0.771 & 0.020 & 0.760 & 38.451 & 0.000 \\
\hline
\end{tabular}

The results of the regression (Table 4 ) indicated that the regression coefficient of promoting intergenerational synergy was $0.771(\beta=0.760)$ and was significantly different from $0(\mathrm{p}<0.001)$. There is a statistically significant positive impact of the independent variable (promoting intergenerational synergy) on the dependent variable (work engagement of older employees).

\section{Discussion}

Based on the results we confirmed the hypothesis that promoting intergenerational synergy in companies has a significant positive impact on the work engagement of older employees in Slovenia. Therefore, companies should pay attention to promoting intergenerational synergy and eliminate the discrimination of older employees. Based on the results in Table 2, we found that employers pay attention to intergenerational synergy in companies in Slovenia, because they on average agree with all statements which describe the construct intergenerational synergy in companies, but there are still open opportunities to raise awareness among employers about intergenerational synergy and their emphasis on intergenerational synergy for better understanding of different age profiles for the customer and their needs. 
Based on the results (Table 3) we also found the most important factor in intergenerational synergy: "In the company we emphasise intergenerational synergy." Through intergenerational cooperation, a company can allow the distribution of work tasks and thereby reduce the workload of older employees, place emphasis on better understanding of the different age profiles of customers and their needs, and exploit the benefits of age diversity among their employees. Thus, a significant advantage of intergenerational synergy is shown in the work engagement of older employees. Results in Table 4 show that, on average, older employees partially agree or agree that they are engaged in their workplace. Also, the highest average agreement is achieved by the statement "I am engaged to the quality of my work." Based on the results (Table 5) we found the most important factor in work engagement of older employees "I do my work with passion." Passionate employees are committed to continually achieving higher levels of performance. In today's rapidly changing business environment, companies need passionate workers because such workers can drive extreme and sustained performance improvement.

Organisations should encourage and know how to effectively transfer the knowledge and experience of older employees to younger employees. The exchange of knowledge and experience is a fundamental way through which employees can contribute to the performance, innovation, and ultimately the competitive advantage of an organisation (see, e.g. Wang/Noe 2010; Zacher/Rudolph 2017; Frerichs/Lindley//Aleksandrowicz/Baldauf/Galloway 2012; Rupčić 2018). Promoting intergenerational synergy helps to increase the added value of the organisation, which is reflected in the improvement of ways to solve problems, exchange of knowledge and experience, increased creativity and innovation, increased organisational flexibility, improved quality of employees by better selection and retention of personnel, and improved market strategies (see, e.g. Sanyal et al. 2015; Zaniboni et al. 2014; Ilmarinen 2012; Profili et al. 2017).

Organisations that are aware of the importance of age diversity among their employees and intergenerational synergy have a great advantage over others, since they can best respond to faster and faster changes in the global environment. Age-diverse employees bring to organisations their different opinions, knowledge, experiences, values, and lifestyles. Age-diverse employees, and thus the establishment of intergenerational synergy in an organisation, contribute to greater productivity, innovation, creativity, motivation, satisfaction, competitiveness, and easier adaptation and acceptance of changes (see, e.g. Naegele/Walker 2006; Beazley et al. 2017; Vasconcelos 2015 b; Harvey 2012; Mahon/Millar 2014). 


\section{Conclusion}

The results of the research on the management of older employees presented in this paper show that promoting intergenerational synergy in companies has a significant positive impact on the work engagement of older employees in Slovenia.

Contribution to theory and practice is reflected in the promotion of awareness of the importance of intergenerational synergy and work engagement of older employees. Overall, age diversity is seen as a benefit to both the organisation and the individual. A workplace with only one generation represented is less effective and not as enjoyable to work in. Employees tend to enjoy working with colleagues of different ages. Different generations are considered to have varied approaches to work, which bring about new perspectives. The presence of representatives from different generations in an organisation can become an important contributor to success, including teamwork success. One benefit of a diverse workforce is the ability to tap into the many talents of employees from different backgrounds, perspectives, abilities, and disabilities. Many companies still face challenges regarding building a diverse environment. Therefore, it is very important to understand and respect the generational differences existing between employees and to use the potential of each employee appropriately, regardless of age, experience, or seniority.

The research is limited to medium-sized and large companies in Slovenia by following the assumption that companies with a smaller number of employees do not have a developed systematic human resource management. The theoretic basis for this assumption is provided by Newell and Scarbrough (2002:86) and Hornsby and Kuratko (2003:74-77), who explain on the basis of research studies that the majority of small companies do not have a human resource professional and that the owner of a small company fulfills this function. The research is limited to the field of older employees and their engagement in the workplace in Slovenia. Another limitation of our research is reflected in the topic about promoting intergenerational synergy and its impact on work engagement of older employees. There are many other factors that influence work engagement of older employees; therefore, it would be interesting to explore impacts of different factors (for example, organizational climate, workload in the workplace, working conditions for older employees) on work engagement of older employees; the description of operationalization in the methodological part of the paper namely allows other scientists to follow the presented methodology. In our research we followed the research process described by Kumar (2005) who pointed out that the steps of this process are operational in nature, following a logical sequence, and that they cover a total spectrum of a research endeavour (Kumar 2005). In this paper, new variables (factors) were defined with consistent consideration of the factor analysis procedure and results. 
Our proposal for further research involves examination of the approaches to establish a intergenerational sinergy in different countries. Further research possibilities also include studies relating to the examination of different measures introduced in different countries to increase engagement in the workplace of older employees. It would be also interesting to make differences in work engagement within age-groups, departments and hierarchical levels.

\section{References}

Age Concern England. (2014): Adding value by joining generations: An intergenerational approach. Retrieved from http://www.age-platform.eu/images/stories/EN/Adding_value_by_j oining_generations.pdf Accessed 18 February 2019

Agrawal, V. (2012): Managing the diversified team: challenges and strategies for improving performance. Team Performance Management: An International Journal, 18 (7/8), 384400 .

Albrecht, S./Breidahl, E./Mart, A. (2018): Organizational resources, organizational engagement climate, and employee engagement. Career Development International, 23 (1), $67-$ 85 .

Alzyoud, A.A.Y. (2018): Job satisfaction and work engagement moderated by trust. International Journal of Economics, Commerce and Management, 6 (11), 1-15.

Appelbaum, S.H./Wenger, R./Pachon Buitrago, C./ Kaur, R. (2016). The effects of old-age stereotypes on organizational productivity (part three). Industrial and Commercial Training, 48(4), 181-188.

Argote, L./McEvily, B./Reagans, R. (2003): Management knowledge in organizations: an integrative framework and review of emerging themes. Management Science, 49 (4), 571582.

Ariani, D. (2013): The relationship between employee engagement, organizational citizenship behavior, and counterproductive work behavior. International Journal of Business Administration, 4 (2), 46-56.

Bakker, A.B. (2009): Building engagement in the workplace. Retrieved from http://citeseerx.i st.psu.edu/viewdoc/download?doi=10.1.1.395.2276\&rep=rep1\&type=pdf Accessed 19 May 2019

Bakker, A.B./Demerouti, E. (2008): Towards a model of work engagement. Career Development International, 13 (3), 209-223.

Bakker, A.B./Albrecht, S.L./Leiter, M.P. (2011): Work engagement: further reflections on the state of play. European Journal of Work and Organizational Psychology, 20 (1), 74-88.

Beazley, A./Ball, C./Vernon, K. (2017): Workplace Age Diversity: The Employers' Perspectives. The Changing Context of Managing People, 225-247.

Brooke, L. (2003): Human resource costs and benefits of maintaining a mature-age workforce. International Journal of Manpower, 24 (3), 260-283.

Cheung, F./Wu, A.M.S. (2013): Older workers' successful aging and intention to stay. Journal of Managerial Psychology, 28 (6), 645-660.

Chronbach, L.J. (1951): Coefficient alpha and the internal structure of tests. Psychometrika, $16,297-334$. 
Churchill, G. A./Brown, T.J. (2004): Basic Marketing Research. (5th ed). Ohio: Mason, Thomson.

Costello, A.M./Osborne, J.W. (2005): Best practices in exploratory factor analysis: Four recommendations for getting the most from your analysis. Practical Assessment, Research \& Evaluation, 10 (7), 1-9.

Cropanzano, R./Wright, T.A. (2001): When a "happy" worker is really a "productive" worker: A review and further refinement of the happy-productive worker thesis. Consulting Psychology Journal Practice and Research, 53 (3), 182-199.

Demerouti, E./Bakker, A.B./De Jonge, J./Janssen, P.P.M./Schaufeli, W.B. (2001): Burnout and engagement at work as a function of demands and control. Scandinavian Journal of Work, Environment \& Health, 27 (4), 279-286.

Davies, E.M.M./Hanley, K./Jenkins, A.K./Chan, C. (2017): Learning and Training for Older Workers. The Changing Context of Managing People, 185-206.

Foundation for the Improvement Of Employment Opportunities. (2012): Intergenerational cooperation. Retrieved from http://www.fundacija-prizma.si/index.php/medgeneracijsko-sode lovanje Accessed 7 March 2019

Frerichs, F./Lindley, R./Aleksandrowicz, P./Baldauf, B./Galloway, S. (2012): Active ageing in organisations: a case study approach. International Journal of Manpower, 33 (6), 666-684.

Garg, K./Dar, I.A./Mishra, M. (2018): Job satisfaction and work engagement: A study using private sector bank managers. Advances in Developing Human Resources, 20 (1), 58-71.

Gruman, J.A./Saks, A.M. (2011): Performance management and employee engagement. $\mathrm{Hu}$ man Resource Management Review, 21 (2), 123-136.

Guan, X./Frenkel, S. (2018): How HR practice, work engagement and job crafting influence employee performance. Chinese Management Studies, 12 (3), 591-607.

Harter J./Adkins, A. (2015): Engaged Employees Less Likely to Have Health Problems. Retrieved from http://www.gallup.com/poll/187865/engaged-employees-less-likely-health-pro blems.aspx?g_source=EMPLOYEE_ENGAGEMENT\&g_medium=topic\&g_campaign=ti les Accessed 3 May 2018.

Harvey, J.F. (2012): Managing organizational memory with intergenerational knowledge transfer. Journal of Knowledge Management, 16 (3), 400-417.

Henkin, N. Z./Butts, D.M. (2012): Intergenerational practice in the United States: past, present and future. Quality in Ageing and Older Adults, 13 (4), pp. 249-256.

Hertel, G./van der Heijden, B.I.J.M./de Lange, A.H./Deller, J. (2013): Facilitating age diversity in organizations - part II: managing perceptions and interactions. Journal of Managerial Psychology, 28 (7/8), 857-866.

Ilmarinen, J. (2006): Towards a longer worklife! Ageing and the quality of worklife in the European Union. Retrieved from www.sopol.at/document/download/towards-a-longer-work life Accessed 3 May 2018.

Ilmarinen, J. (2012): Promoting active ageing in the workplace. European Agency for safety and health at work. Retrieved from https:/osha.europa.eu/en/tools-and-publications/publica tions/articles/promoting-active-ageing-in-the-workplace Accessed 3 May 2018.

Jorgensen, B. (2005): The ageing population and knowledge work: a context for action. Foresight, 7 (1), 61-76. 
Jr, P.I.G./Finkel, E.J./Fitzsimons, G.M./Gino, F. (2017): The energizing nature of work engagement: Toward a new need-based theory of work motivation. Research in Organizational Behavior, 37, 1-18.

Kaiser, H.F. (1974): An Index of Factorial Simplicity. Psychometrika, 39 (1), 31-36.

Karanika-Murray, M./Duncan, N./Halley M.P./Griffiths, M.D. (2015): Organizational identification, work engagement, and job satisfaction. Journal of Managerial Psychology, 30 (8), 1019-1033.

Kluge, A./Krings, F. (2008): Attitudes toward older workers and human resource practice. Swiss Journal of Psychology, 67 (1), 61-64.

Kooij, D./de Lange, A./Jansen, P./Dikkers, J. (2008): Older workers motivation to continue to work: five meanings of age. Journal of Managerial Psychology, 23 (4), 364-394.

Kumar, R. (2005): Research Methodology: A Step-by-Step Guide for Beginners. Sage: Los Angeles.

Li, Y./Castaño, G./Li, Y. (2018): Linking leadership styles to work engagement: The role of psychological capital among Chinese knowledge workers. Chinese Management Studies, $12(2), 433-452$.

Lopes Costa, P./Passos, A.M./Bakker, A.B. (2016): The work engagement grid: predicting engagement from two core dimensions. Journal of Managerial Psychology, 31 (4), 774-789

Lu, L./Lu, A.C.C./Gursoy, D./Neale, N.R. (2016): Work engagement, job satisfaction, and turnover intentions: A comparison between supervisors and line-level employees. International Journal of Contemporary Hospitality Management, 28 (4), 737-761.

Macey, W.H./Schneider, B. (2008): The meaning of employee engagement. Industrial and Organizational Psychology, 1 (1), 3-30.

Mahon, J.F./Millar, C.J.M. (2014): ManAGEment: the challenges of global age diversity for corporations and governments. Journal of Organizational Change Management, 27 (4), $553-568$.

May, D.R./Gilson, R.L./Harter, L.M. (2004): The psychological conditions of meaningfulness, safety and availability and the engagement of the human spirit at work. Journal of Occupational and Organizational Psychology, 77 (1), 11-37.

Ministry of Labour, Family, Social Affairs and Equal Opportunities. (2017): Increasing employment of older workers in Slovenia. Retrieved from http:/www.mddsz.gov.si/fileadmin/ mddsz.gov.si/pageuploads/dokumenti_pdf/zaposlovanje/Razvoj_strategij_reform_na_podr ocju_socialnih_politik_v_Sloveniji/Helping_older_workers_in_the_labour_market_Aug_2 017.pdf Accessed 18 November 2018

Naegele, G./Walker, A. (2006): A guide to good practice in age management, European foundation for the improvement of living and working conditions. Retrieved from http://www.e urofound.europa.eu/publications/htmlfiles/ef05137.htm Accessed 18 November 2018

Noack, C.M.G. (2009): Age climate. Age stereotypes in organizations and older workers. Jacobs University.

Oliveira, E./Cabral-Cardoso, C. (2017): Older workers' representation and age-based stereotype threats in the workplace. Journal of Managerial Psychology, 32 (3), 254-268.

Oliveira, E./Cabral-Cardoso, C. (2018): Stereotype threat and older worker's attitudes: a mediation model. Personnel Review, 47 (1), 187-205. 
Pham-Thai, N.T./McMurray, A.J./Muenjohn, N./Muchiri, M. (2018): Job engagement in higher education. Personnel Review, 47 (4), 951-967.

Posthuma, R.A./Campion, M.A. (2009): Age stereotypes in the workplace: common stereotypes, moderators, and future research directions. Journal of Management, 35 (1), 158-188.

Prizma. (2018): Intergenerational cooperation. Retrieved from http://www.fundacija-prizma.si /index.php/medgeneracijsko-sodelovanje Accessed 18 November 2018.

Profili, S./Innocenti, L./Sammarra, A. (2017): A Conceptual Framework of Age Diversity Climate. Advanced Series in Management, 17, 95-116.

Putra, E.D./Cho, S./Liu, J. (2015): Extrinsic and intrinsic motivation on work engagement in the hospitality industry: Test of motivation crowding theory. Tourism and Hospitality Research, 17(2), 228-241.

Robertson, I.T./Cooper, C.L. (2010): Full engagement: the integration of employee engagement and psychological well-being. Leadership \& Organization Development Journal, 31 (4), 324-336.

Ropes, D. (2014): Integrational learning in organizations. An effective way to stimulate older employee learning and development. Development and learning organizations, 28 (2), 7-9.

Roscigno, V.J./Mong, S./Byron, R./Tester, G. (2007): Age discrimination, social closure and employment. Social Forces, 86 (1), 313-334.

Rupčić, N. (2018): Intergenerational learning and knowledge transfer - challenges and opportunities. The Learning Organization, 25 (2), 135-142.

Saks, A.M. (2006): Antecedents and consequences of employee engagement. Journal of Managerial Psychology, 21 (7), 600-619.

Sanyal, C./Wilson, D./Sweeney, C./Rachele, J.S./Kaur, S./Yates, C. (2015): Diversity and inclusion depend on effective engagement: It is everyone's business to ensure that progress is maintained. Human Resource Management International Digest, 23 (5), 21-24.

Schaufeli, W.B. (2012): Work engagement. What do we know and where do we go? Work engagement in everyday life, business, and academia. Retrieved from https://www.researchgat e.net/publication/230580677_Work_Engagement_What_Do_We_Know_and_Where_Do_ We_Go_Work_Engagement_in_Everyday_Life_Business_and_Academia Accessed $\overline{2} 0$ May 2019

Schaufeli, W.B./Bakker, A.B. (2004): Job demands, job resources and their relationship with burnout and engagement: A multi-sample study. Journal of Organizational Behavior, 25 (3), 293-315.

Schaufeli, W.B./Salanova, M. (2007): Work engagement. An emerging psychological concept and its implications for organizations. Retrieved from http://www.want.uji.es/wp-content/u ploads/2017/10/2007_Schaufeli-Salanova-Work-Engagement-an-emerging-psychological-c oncept-.pdf Accessed 19 May 2019

The Employers Forum on Age. (2014): Your rights in work. Retrieved from http://www.efa.or g.uk/publications.php Accessed 3 May 2018.

Tikkanen, T./Nyhan, B. (2006): Promoting lifelong learning for older workers. An international overview. Retrieved from http://www.cedefop.europa.eu/files/3045_en.pdf Accessed 18 November 2018.

Truxillo, D.M./Fraccaroli, F. (2013): Research themes on age and work: Introduction to the Special Issue. European Journal of Work and Organizational Psychology, 22 (3), 249-52. 
Vasconcelos, A.F. (2015 a): Older workers: some critical societal and organizational challenges. Journal of Management Development, 34 (3), 352-372.

Vasconcelos, A.F. (2015 b): The contemporary experience of work: older workers' perceptions. Management Research Review, 38 (4), 381-403.

Vincent-Höper, S./Muser, C./Janneck, M. (2012): Transformational leadership, work engagement, and occupational success. Career Development International, 17 (7), 663-682.

Wagner, R./Harter, J.K. (2006): 12: The Elements of Great Managing. New York: Gallup Press.

Walker, A. (2012): A strategy for active ageing. International Social Security Review, 55 (1), 121-139.

Wang, S./Noe, R.A. (2010): Knowledge sharing: a review and directions for future research. Human Resource Management Review, 20 (2), 115-131.

Willet, M. (2005): Early retirement and phased retirement. Benefits and compensation digest, $42,31-36$.

$\mathrm{Xu}$, J./Thomas, H.C. (2011): How can leaders achieve high employee engagement? Leadership \& Organization Development Journal, 32 (4), 399-416.

Yiing, L.H./Ahmad, K.Z.B. (2009): The moderating effects of organizational culture on the relationships between leadership behaviour and organizational commitment and between organizational commitment and job satisfaction and performance. Leadership \& Organization Development Journal, 30 (1), 53-86.

Zacher, H./Rudolph, C.W. (2017): Successful Aging at Work and Beyond: A Review and Critical Perspective. Advanced Series in Management, 17, 35-64.

Zaniboni, S.M./Truxillo, D./Fraccaroli, F./McCune, E.A./Bertolino, M. (2014): Who benefits from more tasks? Older versus younger workers. Journal of Managerial Psychology, 29 (5), 523-508.

Žnidaršič, J. (2010): Age management in Slovenian enterprises: the viewpoint of older employees. Zbornik Radova Ekonomskog Fakulteta u Rijeci, 28 (2), 271-301.

Žnidaršič, J./Dimovski, V. (2010): Reluctance Towards Older Workers In Slovenia. International Business \& Economics Research Journal, 9 (2), 83-100. 